\title{
Perbandingan Zat Penyusun Dalam Pemanfaatan Limbah Cair Tahu Sebagai Energi Alternatif Biogas
}

\author{
Nasyiruloh Dwi Susetyo ${ }^{1)}$, Fatkur rhohman'), M. Muslimin Ilham ${ }^{3)}$. \\ 1), 2),3) Teknik Mesin, Universitas Nusantara PGRI Kediri \\ E-mail: ${ }^{1)}$ nasirsusetyo@gmail.com, ${ }^{2)}$ fatkurrohman@ unpkediri.ac.id , \\ 3)im.muslimin@unpkediri.ac.id
}

\begin{abstract}
Abstrak
Limbah padat dan cair pada pembuatan tahu cukup menggangu masyarakat. Pembuatan tahu di kediri masih menggunakan cara tradisional sehingga tingkat efisiensi penggunaan sumber daya (air dan bahan baku) dirasakan masih rendah dan tingkat produksi limbahnya juga relatif tinggi. Bioenergy merupakan sumber energi yang dihasilkan oleh sumber daya hayati seperti tumbuh - tumbuhan, minyak nabati, dan limbah peternakan dan pertanian. Jenis energi yang dihasilkan berupa energi dalam bentuk gas, cair, atau padat. Energi tersebut selanjutnya dapat digunakan untuk menghasilkan panas, gerak, dan listrik tergantung pada alat yang digunakan dan kebutuhan pengguna. Biogas adalah campuran gas yang dihasilkan dari aktivitas bakteri metanogenik pada kondisi anaerobik atau fermentasi bahan-bahan organik. Biogas merupakan produk dari pendegradasian substrat organik secara anaerobik. Karena proses ini menggunakan kinerja campuran mikroorganisme dan tergantung terhadap berbagai faktor seperti suhu, $\mathrm{pH}$, hydraulic retention, rasio $\mathrm{C}: \mathrm{N}$ dan sebagainya sehingga proses ini berjalan lambat. Penelitian ini bertujuan untuk mengetahui erbandingan zat penyusun dalam pemanfaatan limbah cair produksi tahu sebagai energi alternatif biogas. Untuk membuat biogas alat yang digunakan antara lain: Digester dan manometer. Bahan baku yang digunakan untuk komposisi pertama adalah limbah tahu cairan pertama 30 liter dengan $50 \mathrm{ml}$ Em4 dan air kelapa 2 liter. Sedangkan untuk komposisi kedua adalah limbah tahu cairan pertama sebanyak 30 liter dengan $50 \mathrm{ml}$ Em4 dan molase $500 \mathrm{ml}$. Data diambil selama 14 hari dengan pengamatan dilakukan setiap hari. Dari hasil uji prasyarat normalitas, diperoleh bahwa kedua data berdistribusi normal. Sedangkan hasil uji prasyarat homogenitas, dinyatakan bahwa data bersifat homogen. Karena yang dibandingkan adalah 2 data, maka cukup menggunakan Uji-T. Dari hasil Uji-T, diperoleh bahwa komposisi kedua lebih baik daripada komposisi pertama. Sehingga daat disimpulkan bahwa pembuatan biogas dari limbah cair yang ditambahkan dengan molase memberikan hasil yang lebih baik daripada pembuatan biogas dari limbah cair tahu ditambah dengan air kelapa.
\end{abstract}

Kata Kunci : Air kelapa, Biogas, Em4, Limbah cair tahu, Molase.

\section{Abstract}

Waste Solid and liquid in production is disturbing to the humans. Production tofu in Kediri use traditional methods, so the level of efficiency in the use of resources is low and the level of waste production is high. Bioenergy is a source of energy produced by biological resources such as plants, vegetable oils, and livestock and agricultural waste. The type of energy produced is gas, liquid, or solid form. The energy can be used to produce heat, motion, and electricity, depending on the needs. Biogas is a gas mixture produced from the activity of methanogenic bacteria under anaerobic conditions or 
fermentation of organic materials. Biogas is a product of anaerobic degradation of organic substrates. Because this process uses the performance of a mixture of microorganisms and depends on various factors such as temperature, $\mathrm{pH}$, hydraulic retention, $C: N$ ratio and so on, so this process runs slowly. This study aims to determine the comparison of constituents in the utilization of tofu waste water production as an alternative biogas energy. To make biogas tools used include: Digester and manometer. The raw material used for the first composition is 30 liter first tofu liquid waste with 50 ml Em4 and 2 liter coconut water. As for the second composition, the first liquid tofu waste is 30 liters with $50 \mathrm{ml} \mathrm{Em4}$ and $500 \mathrm{ml}$ molasses. Data was taken for 14 days with observations made every day. From the results of the normality test, it was found that the both of data were normally distributed. While the homogeneity test results, it is stated that the data are homogeneous. Because what is compared is 2 data, it is sufficient to use the T-Test. T-Test results show that the second composition is better than the first composition. So it can be concluded that making biogas from liquid waste added with molasses gives better results than making biogas from tofu liquid waste added with coconut water.

Keyword: coconut water, biogass, Em4, waste liquid of tofu, molase.

\section{PENDAHULUAN}

Limbah padat dan cair pada kehidupan sehari-hari di wilayah industri rumahan seperti pembuatan tahu cukup menggangu masyarakat baik dari sisi kesehatan maupun sisi keharmonisan dalam bermasyarakat. Industri rumahan pembuatan tahu di lingkungan sekitar khususnya di wilayah kediri masih menggunakan cara tradisional sehingga tingkat efisiensi penggunaan sumber daya (air dan bahan baku) dirasakan masih rendah dan tingkat produksi limbahnya juga relatif tinggi. Jika limbah tidak diolah dengan baik, maka akan menimbulkan bau akibat proses pembusukan bahan organik oleh bakteri. Di dalam Pasal 14 ayat (1) Undangundang Republik Indonesia Nomor 23 tahun 1997 tentang pengelolaan lingkungan hidup disebutkan, untuk menjamin pelestarian fungsi lingkungan hidup, setiap usaha dan atau kegiatan dilarang melanggar baku mutu dan kriteria baku kerusakan lingkungan. Adapun hal yang menyebabkan keharusan. Setiap warga untuk melakukan proses penghematan karena pasokan bahan bakar yang berasal dari minyak bumi merupakan sumber energi fosil yang tidak dapat diperbarui (unrenewable), sementara permintaan menunjukkan kecenderungan yang terus meningkat dan demikian pula dengan kondisi harga sehingga tidak ada stabilitas keseimbangan antara permintaan dan penawaran[1]. Salah satu jalan untuk melakukan penghematan BBM adalah dengan mencari sumber energi alternatif terutama yang dapat diperbarui (renewable). Sebagai contoh energi biogas[2]. 
Limbah tahu dalam bentuk padat maupun cair, mengandung bahan organic dan nutrient tinggi. Limbah padat tahu (ampas tahu) memiliki kadar protein 24,77\% dengan kadar karbohidrat sebesar 25,46\%. Sedangkan serat kasar 23,58\%[3]. Sedangkan limbah cair tahu terdiri dari air $90,72 \%$, protein $1,8 \%$, lemak $1,2 \%$, serat kasar 7,36\%, dan abu 0,32\%[4]. Limbah cair dari tahu yang paling berbahaya apabila dibuang secara langsung ke lingkungan adalah whey yang merupakan hasil samping proses penggumpalan dan kandungan bahan organiknya sangat tinggi[5]. Sebagian besar buangan pabrik tahu adalah limbah cair yang mengandung sisa air dari susu tahu yang tidak tergumpal menjadi tahu,sehingga limbah cair pabrik tahu masih mengandung zat-zat organik seperti protein, karbohidrat dan lemak. Selain zat terlarut, limbah cair juga mengandung padatan tersuspensi atau padatan terendapkan misalnya potongan tahu yang kurang sempurna saat pemrosesan[6]. Dengan melihat komposisi limbah tersebut, maka system anaerobik sangat tepat untuk mengolah limbah cair tahu. Pengolahan langsung dengan anaerobic menghadapi banyak kendala seperti timbulnya busa dan banyaknya bahan organik yang tidak terdegradasi.

Karakteristik limbah cair tahu antara lain [7]: Temperatur limbah cair tahu biasanya tinggi $\left(60-80^{\circ} \mathrm{C}\right)$ karena proses pembuatan tahu butuh suhu tinggi pada saat penggumpalan dan penyaringan. Warna air buangan transparan sampai kuning muda dan disertai adanya suspensi warna putih. Zat terlarut dan tersuspensi mengalami penguraian hayati maupun kimia sehingga berubah warna. Proses ini merugikan karena air buangan berubah menjadi warna hitam dan busuk yang member nilai estetika kurang baik. Bau air buangan industri tahu dikarenakan proses pemecahan protein oleh mikroba alam sehingga timbul bau busuk dari gas H2S. Kekeruhan pada limbah disebabkan oleh adanya padatan tersuspensi dan terlarut dalam limbah cair pabrik tahu.

Bio energy merupakan sumber energi (bahan bakar) yang dihasilkan oleh sumber daya hayati seperti tumbuh - tumbuhan, minyak nabati, dan limbah peternakan dan pertanian. Jenis energi yang dihasilkan berupa energy dalam bentuk gas (biogas), cair (biofuel), atau padat (biomas). Energi tersebut selanjutnya dapat digunakan untuk menghasilkan panas (kalor), gerak (mekanik), dan listrik tergantung pada alat yang digunakan dan kebutuhan pengguna. Dengan kekayaan 
dan keragaman sumber daya hayati yang ada di Indonesia, pemanfaatan bioenergi merupakan pilihan yang tepat dalam rangka penyediaan energi yang terbarukan, murah dan ramah lingkungan[8].

Biogas adalah campuran gas yang dihasilkan dari aktivitas bakteri metanogenik pada kondisi anaerobik atau fermentasi bahan-bahan organik. Biogas merupakan produk dari pendegradasian substrat organik secara anaerobik. Karena proses ini menggunakan kinerja campuran mikroorganisme dan tergantung terhadap berbagai faktor seperti suhu, $\mathrm{pH}$, hydraulic retention, rasio $\mathrm{C}: \mathrm{N}$ dan sebagainya sehingga proses ini berjalan lambat[10]. Menurut Indiartono, teknologi biogas pada dasarnya memanfaatkan proses pencernaan yang dilakukan oleh bakteri metanogen yang produknya berupa gas metan $(\mathrm{CH} 4)$ yang mencapai $60 \%$. Bakteri ini bekerja pada lingkungan yang tidak ada udara (anaerob), sehingga proses ini juga disebut pencernaan anaerob (anerob digestion) [11].

Satu (1) m3 biogas, setara dengan elpiji 0,46 kg, Minyak tanah 0,62 liter, minyak solar 0,52 liter, bensin 0,80 liter, dan kayu bakar 3,5 kg. Dengan melihat hal demikian maka di butuhkan penanganan yang mampu membuat limbah cair yang langsung dibuang tersebut menjadi bahan bakar alternatif yang murah, efisien, dan ramah lingkungan[11]. Berdasarkan penjelasan di atas, sepanjang pengetahuan dan kemampuan peneliti, maka peneliti tertarik mengadakan penelitian dengan mengambil judul "Perbandingan Zat Penyusun Dalam Pemanfaatan Limbah Cair Produksi Tahu Sebagai Energi Alternatif Biogas".

\section{METODE PENELITIAN}

Untuk membuat biogas alat yang digunakan antara lain: Digester dan manometer. Digester merupakan alat utama dalam pembentukan biogas dalam proses fermentasi, kondisi digester yang akan digunakan sebagai media fermentasi harus dipastikan dalam kondisi baik, tahan terhadap zat asam karenan bahan utama adalah limbah tahu cair yang mempunyai tingkat keasaman cukup tinggi dan yang tidak kalah penting harus kedap udara. Manometer psi merupakan alat bantu yang wajib dipakai karena untuk mendeteksi perkembangan fermentasi yang meghasilkan gas di dalam biodigester karena apabila menggunakan regulator kompor gas hasil gas tidak dapat ditunjukkan sebab tekanan yang relatif kecil. 
Adapun urutan dalam proses diagram alir pada penelitian ini sebagai berikut :

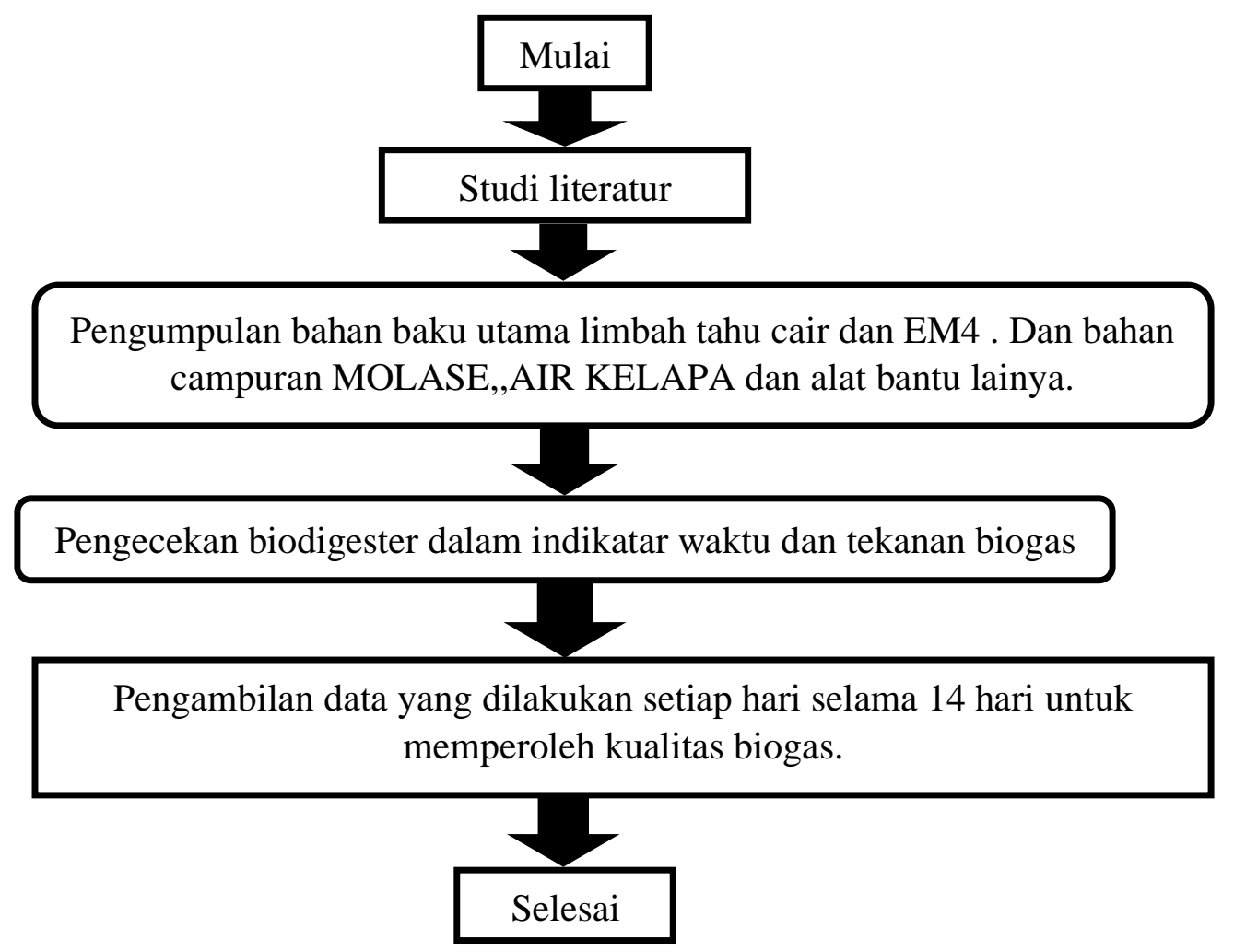

Gambar 1. Diagram Alir Penelitian

Proses pembuatan biogas yang dilakukan antara lain:

a. Menyiapkan bahan baku limbah tahu cair sebanyak 30 liter dengan $50 \mathrm{ml} \mathrm{Em4}$ dan dicampurkan dengan bahan perbandingan : air kelapa 2 liter : molase 500 $\mathrm{ml}$.

b. Setelah semua bahan sudah terkumpul masukkan semua bahan tersebut kedalam biodigester dan aduk hingga semua bahan tercampur.

c. Tutup rapat biodigester agar fermentasi terjadi usahakan kadar oksigen dalam digester rendah agar hasil maksimal.

d. Diamkan selama 14 hari agar terbentuk gas yang diinginkan

e. Setelah hari hari ke 1 sudah diambil data selama 14 hari

\section{HASIL DAN PEMBAHASAN}

Dalam penilitian ini, variabel bebas yang nilainya dapat dikendalikan dalam penelitian ini yaitu air kelapa sebanyak 2 liter dan limbah cair tahu sebanyak 8 liter. Sedangkan variabel terikatnya adalah produksi biogas yang bisa dilihat melalui peningkatan tekanan dalam manometer. 
Tabel 1. Data hasil penelitian

\begin{tabular}{|c|c|c|c|}
\hline \multirow{2}{*}{ No } & \multirow{2}{*}{ Waktu } & \multicolumn{2}{|c|}{ Tekanan biogas (psi) } \\
\cline { 3 - 4 } & & Data 1 & Data 2 \\
\hline 1 & Hari ke 1 & 0 & 2 \\
\hline 2 & Hari ke 2 & 0 & 3 \\
\hline 3 & Hari ke 3 & 0 & 3,5 \\
\hline 4 & Hari ke 4 & 1,7 & 4 \\
\hline 5 & Hari ke 5 & 3,5 & 4,5 \\
\hline 6 & Hari ke 6 & 4 & 5 \\
\hline 7 & Hari ke 7 & 4,1 & 6 \\
\hline 8 & Hari ke 8 & 4,7 & 7 \\
\hline 9 & Hari ke 9 & 4,9 & 8 \\
\hline 10 & Hari ke 10 & 4,9 & 9 \\
\hline 11 & Hari ke 11 & 4,9 & 10 \\
\hline 12 & Hari ke 12 & 4,9 & 12 \\
\hline 13 & Hari ke 13 & 6,5 & 13 \\
\hline 14 & Hari ke 14 & 6,5 & \\
\hline
\end{tabular}

Data yang didapat yang sebelumya dicatat akan di lakukan pengujian.

\section{a. Uji normalitas produksi Biogas dengan penambahan air kelapa}

Dalam pengujian normalitas dapat dipaparkan hasil pengujiannya yang sebelumnya sudah dicatat datanya ditabel 2 :

Tabel 2. Hasil Uji Normalitas data produksi Biogas ditambah air kelapa One-Sample Kolmogorov-Smirnov Test

\begin{tabular}{|ll|r|}
\hline & & \multicolumn{1}{|c|}{ air kelapa } \\
\hline$N$ & & 14 \\
Normal Parameters ${ }^{a, b}$ & Mean & 3,6143 \\
& Std. Deviation & 2,28199 \\
Most Extreme Differences & Absolute &, 210 \\
& Positive &, 158 \\
& Negative &,- 210 \\
Test Statistic &, 210 \\
Asymp. Sig. (2-tailed) &, $095^{c}$ \\
\hline a. Test distribution is Normal. \\
b. Calculated from data. \\
c. Lilliefors Significance Correction.
\end{tabular}

Hipotesis yang digunakan adalah :

$\mathrm{H}_{0}=$ Residual biogas dengan penambahan air kelapa berdistribusi normal 
$\mathrm{H}_{1}=$ Residual biogas dengan penambahan air kelapa tidak berdistribusi normal $\mathrm{H}_{0}$ dinyatakan diterima jika $\mathrm{P}-\mathrm{Value}>0,05$ atau T-Test $>\mathrm{T}$-Tabel. Dari output di atas, diperoleh Asymp. Sig. (2-Tailed) (P-Value) = 0,095 > 0,05 atau $\mathrm{H}_{0}$ diterima. Dengan demikian, residual biogas dengan penambahan air kelapa bersidtribusi normal.

\section{b. Uji normalitas produksi Biogas dengan penambahan molase}

Dalam pengujian normalitas dapat dipaparkan hasil pengujiannya yang sebelumnya sudah dicatat datanya ditabel 3 :

Tabel 3. Hasil Uji Statik untuk Normalitas data produksi Biogas dengan penambahan molase

One-Sample Kolmogorov-Smirnov Test

\begin{tabular}{|ll|r|}
\hline & & \multicolumn{1}{|c|}{ molase } \\
\hline$N$ & Mean & 14 \\
Normal Parameters & a,b & 6,1429 \\
& Std. Deviation & 3,44422 \\
Most Extreme Differences & Absolute &, 130 \\
& Positive &, 130 \\
& Negative &,- 083 \\
Test Statistic & &, 130 \\
Asymp. Sig. (2-tailed) & &, $200^{c, d}$ \\
\hline
\end{tabular}

a. Test distribution is Normal.

b. Calculated from data.

c. Lilliefors Significance Correction.

$d$. This is a lower bound of the true significance.

Hipotesis yang digunakan adalah:

$\mathrm{H}_{0}=$ Residual biogas dengan penambahan molase berdistribusi normal

$\mathrm{H}_{1}=$ Residual biogas dengan penambahan molase tidak berdistribusi normal

$\mathrm{H}_{0}$ dinyatakan diterima jika $\mathrm{P}-$ Value $>0,05$ atau T-Test $>\mathrm{T}$-Tabel. Dari output di atas, diperoleh Asymp. Sig. (2-Tailed) (P-Value) = 0,200 > 0,05 atau $\mathrm{H}_{0}$ diterima. Dengan demikian, residual biogas dengan penambahan air kelapa bersidtribusi normal.

\section{c. Uji homogenitas}

Dalam pengujian homogenitas dapat dipaparkan hasil pengujian nya yang sebelumnya sudah dicatat datanya pada tabel 4 : 
Tabel 4. Levene's Test of Equality of Error Variances ${ }^{a}$

Dependent Variable: sampel

\begin{tabular}{|c|c|c|c|}
\hline$F$ & $d f 1$ & $d f 2$ & Sig. \\
\hline 3,348 & 1 & 26 & 079 \\
\hline
\end{tabular}

Tests the null hypothesis that the error variance of the

dependent variable is equal across groups.

a. Design: Intercept + kelompok

$\mathrm{H}_{0}=$ Data residual biogas homogen

$\mathrm{H}_{1}=$ Data residual biogas tidak homogen

$\mathrm{H}_{0}$ dinyatakan diterima jika $\mathrm{P}-$ Value $>0,05$ atau T-Test $>\mathrm{T}$-Tabel. Dari output di atas, diperoleh Sig. (P-Value) $=0,079>0,05$ atau $\mathrm{H}_{0}$ diterima. Dengan demikian, residual biogas Homogen.

\section{d. UJI -T}

Setelah dilakukan uji normalitas dan uji homogenitas, maka dilakukan uji untuk mengetahui signifikansi perbedaan rerata dari dua data yang telah ada. Salah satu metode yang bisa digunakan adalah Uji-T. Hasil perhitungan tergambar pada tabel 5.

Tabel 5. Tabel Hasil Uji T

Independent Samples Test

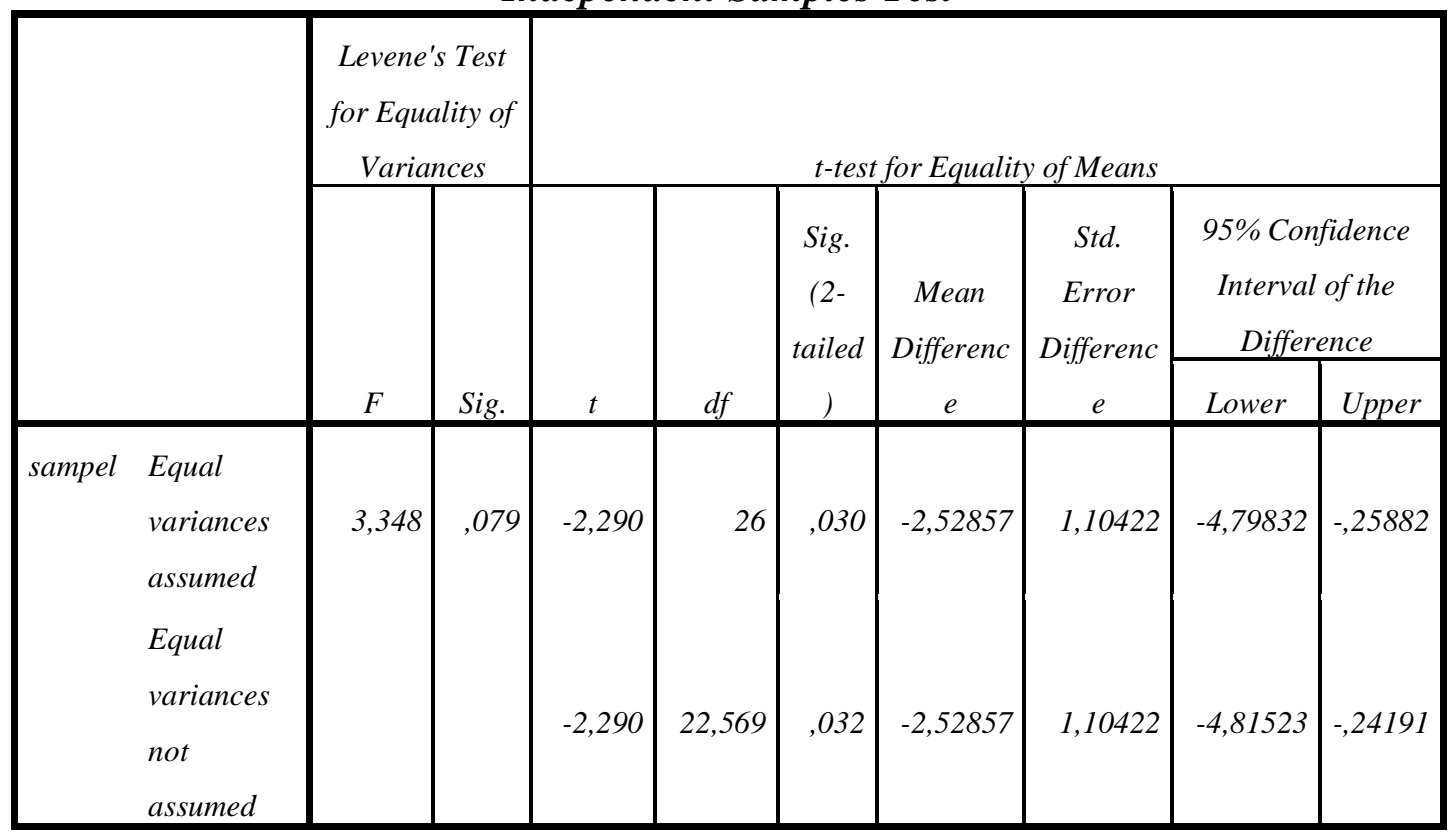

Hipotesis yang digunakan adalah : 
$\mathrm{H}_{0}=$ Terdapat perbedaan yang signifikan antara penambahan air kelapa dan molase $\mathrm{H}_{1}=$ Tidak terdapat perbedaan yang signifikan antara penambahan air kelapa dan molase

$\mathrm{H}_{0}$ dinyatakan diterima jika $\mathrm{P}-$ Value $<0,05$ atau T-Test $>\mathrm{T}$-Tabel. Dari output di atas, diperoleh Sig. 2-Tailed (P-Value) $=0,030 / 2=0,015<0,05$ atau $\mathrm{H}_{0}$ diterima. Dengan demikian, Terdapat perbedaan yang signifikan antara penambahan air kelapa dan molase.

Tabel 6. Perbandingan rerata data

Group Statistics

\begin{tabular}{|l|r|r|r|r|r|}
\hline & kelompok & \multicolumn{1}{|c|}{$N$} & \multicolumn{1}{c|}{ Mean } & $\begin{array}{c}\text { Std. } \\
\text { Deviation }\end{array}$ & $\begin{array}{c}\text { Std. Error } \\
\text { Mean }\end{array}$ \\
\hline sampel & air kelapa & 14 & 3,6143 & 2,28199 &, 60989 \\
& molase & 14 & 6,1429 & 3,44422 &, 92051 \\
\hline
\end{tabular}

Dari rata-rata uji 1 (pencampuran limbah tahu cair dengan EM4 dan air kelapa) adalah 3,6143. Sedangkan rata-rata uji 2 (pencampuran limbah tahu cair dengan EM4 dan Molase) adalah 6,1429. Sehingga rata-rata uji 2 lebih tinggi daripada ratarata pada uji 1. Hal tersebut menunjukkan bahwa komposisi pada bahan kedua lebih baik daripada komposisi pada bahan pertama.

\section{KESIMPULAN}

Dari hasil penelitian, diperoleh hasil bahwa pembuatan biogas dari limbah cair yang ditambahkan dengan molase memberikan hasil yang lebih baik daripada pembuatan biogas dari limbah cair tahu ditambah dengan air kelapa. Bahkan perbedaan keduanya cukup signifikan. Rata-rata selama 14 hari dari hasil produksi biogas limbah cair tahu yang di tambah molase adalah 6,1429 psi. Jauh lebih besar dari pada yang dihasilkan dari limbah cair tahu ditambah dengan air kelapa yang hanya 3,6143 psi.

\section{DAFTAR PUSTAKA}

[1] Undang-undang Republik Indonesia Nomor 23 tahun 1997 tentang pengelolaan lingkungan hidup Pasal 14 ayat (1) 
[2] Coniwati, Pamila; Herlanto, Anton; dan Anggraini, I. Y. 2009. Pembuatan Biogas Dari Ampas Tahu. Jurnal Teknik Kimia, No. 1, Vol. 16, Januari 2009

[3] Rhohman, F. \& Budiretnani, D.A. (2018). Optimalisasi Proses Produksi Tahu Untuk Peningkatan Kesejahteraan Produsen Tahu. Jurnal PanritaAbdi, 2(2), 113-118.

[4] Azhari, Muh.; Sunarto; dan Wiryanto. (2015).Pemanfaatan Limbah Cair Tahu Menjadi Nata De Soya Dengan Menggunakan Air Rebusan Kecambah Kacang Tanah Dan Bakteri Acetobacter Xylinum. Jurnal EKOSAINS Vol. VII No. 1 Maret 2015

[5] Wagiman. 2007. Identifikasi Potensi Produksi Biogas dari Limbah Cair Tahu dengan Reaktor Upflow Anaerobic Sludge Blanket (UASB). Bioteknologi 4 (2): 41-45, Nopember 2007

[6] Nurhasan, Pramudyanto. 1991. Penanganan air limbah tahu dalam uniek M.C.,Clara, 1999. Pemanfaatan limbah cair tahu untuk produksi enzimaamilase dari Bacillus amyloliquefaciens. Skripsi jurusan TPHP, Fakultas Teknologi Pertaian, UGM, Yogyakarta.

[7] Nurhasan dan Pramudyanto. 1991. Penanganan air limbah pabrik tahu. Yayasan Bina Karya Lestari (Bintari).http://www.menlh.go.id/usahakecil/index-view.php?sub=7 (diakses pada 2 September 2019)

[8] Yudiswantoro, Fajar.2016. Pembuatan Energi Biogas Dari Fermentasi Kulit Buah Nanas Dengan Biodigester Berkapasitas 200 Liter.Kediri: FT UN PGRI

[9] Saputro, Rianto Prayogo. 2017. Kinetika Pembuatan Biogas Dari Substrat Kulit Kopi Dengan Mikroorganisme Kotoran Sapi Dan Rumen. Skripsi. Institut Teknologi Sepuluh Nopember: Surabaya

[10] Indiartono, Y. S. 2006. Reaktor Biogas Skala Kecil/Menengah. (http://www.indeni.org/content/view/63/48/. Diakses 21 Agustus 2019)

[11] GTZ. $1997 . \quad$ Biogas Utilization. http://vvw5.gtz.de/gate/techinfo/biogas/appldev/operatiori/utilizat.html. 